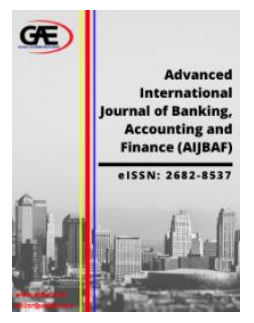

\author{
ADVANCED INTERNATIONAL JOURNAL OF \\ BANKING, ACCOUNTING AND FINANCE \\ (AIJBAF) \\ WWW.aijbaf.com
}

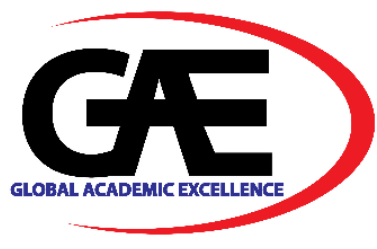

\title{
KAIZEN PRACTICES AMONG ACCOUNTING STUDENTS AND LECTURERS IN AZMAN HASHIM INTERNATIONAL BUSINESS SCHOOL
}

\author{
Nurhidayah Abu Hashim ${ }^{1}$, Nursyazwani Mohd Fuzi ${ }^{2 *}$ \\ 1 Azman Hashim International Business School, Universiti Teknologi Malaysia (UTM), Malaysia \\ Email: hidayahabuhashim@gmail.com \\ 2 Azman Hashim International Business School, Universiti Teknologi Malaysia (UTM), Malaysia \\ Email: nursyazwani.mohdfuzi@utm.my \\ Corresponding Author
}

\section{Article Info:}

Article history:

Received date: 28.02 .2021

Revised date: 15.03 .2021

Accepted date: 18.03.2021

Published date: 31.03 .2021

\section{To cite this document:}

Hashim, N. A., \& Fuzi, N. M. (2021). Kaizen Practices among Accounting Students and Lecturers in Azman Hashim International Business School. Advanced International Journal of Banking, Accounting, and Finance, 3 (6), 61-68.

DOI: $10.35631 /$ AIJBAF.36006.

This work is licensed under $\underline{\mathrm{CC} B Y} 4.0$

\section{(ㅇ)(1)}

\begin{abstract}
:
The implementation of Kaizen had widely been adopted in many organizations. Higher Education Institutions (HEI) is one of the organizations that there is no exception in practicing Kaizen to enhance the continuous improvement in their education institution performance. The objective of this study is to identify the Kaizen practices among accounting students and lecturers in Azman Hashim International Business School. The researcher will use a quantitative approach by distributing questionnaires to obtain data from respondents. The researcher concludes that Kaizen practices are suitable to be implemented in higher education institution because it gives huge advantages towards the entire organizational performance. Education institutions should guide the Kaizen practices to create a culture of ongoing improvement to improve the education system from time to time in the future.
\end{abstract}

Keywords:

Kaizen, Organizational Performance, Accounting Students

\section{Introduction}

According to Reddy and Karim (2015), Kaizen has been introduced in 1950. Masaaki Imai was the founder who had adopted Kaizen in Japanese management which promote the concept of 
Volume 3 Issue 6 (March 2021) PP. 61-68

DOI 10.35631/AIJBAF.36006

continuous quality improvement that aims only for industrial operation effectiveness in Japan. However, this concept of Kaizen has been implemented widely in various type of organizations (Sapungan \& Cuarteros, 2018). Nowadays, the implementation of Kaizen is not only limited for manufacturing sector, but it is also being practice in service sector, government sector as well as non- profit organizations. Kaizen is a tool to implement endless improvement in the organization that involving the cooperation from everybody in the operation such as managers, workers and others (Nazir, 2013). The Kaizen practices also encourage the development of leadership skills among the managers to influence the bottom workers and manager can use their power to lead the Kaizen practices become successful.

Asaad, Saad, and Yusoff (2015) pointed out that there are three main characteristics of Kaizen which the main focus of Kaizen was to implement an endless improvement decision to enhance good and better quality as well as developing an excellent performance towards the employee's involvement. Second, generally Kaizen will focus on improving the nature of work area rather than discontinue or altering the flaws. Third, engagement from the level employees is vital to require in Kaizen for ensuring the knowledge sharing and employee development can be achieved. Kaizen practices must have a systematic structure and guideline. In order to ensure the proper guidelines, manager as a leader have to make a proper planning to overcome the loopholes in the organization and try to implement the proposal of continuous improvement to the workers in the organization for their involvement (Mano, Akoten, Yoshino, \& Sonobe, 2014). Thus, the objective of this study is to identify the implementation of Kaizen practices among accounting students and lecturers.

Practicing Kaizen in education institution could also promotes the elimination of waste. There are many aspects of waste elimination can be achieved through Kaizen implementation. The elimination of waste in terms of resources, time and energy like an excessive file and the used of papers can be abolished to reduce cost. This mean that the practices of Kaizen are prioritizing the task that give an important effect and terminating the task that are likely unnecessary to be done. Therefore, the improvement regarding environment well-being can be achieved. Not only that, it will bring toward the better culture for the satisfaction of the colleagues in the institutions (Sapungan \& Cuarteros, 2018).

Therefore, practicing Kaizen in teaching and learning system can encourage the creativity development and motivation enhancement to the lecturers and students in the classroom. The new strategy of instruction used by the students will assist the students to gain new interesting knowledge and skills. Kaizen practices usually will go along with the need and satisfaction as well as the current trend such as utilizing the benefits of technology. Following the preference of student can assist them to increase their motivation to enjoy the teaching and learning session in the classroom. Hence, this will facilitate the educator goals to achieve the organizational performance.

\section{Problem Statement}

As mentioned by Kregel (2019), an implementation of Kaizen practices in the higher education institution (HEI) had gave many positive impacts towards the performance of education institution. In their studies, they found that many universities have started to develop Kaizen practices such as course evaluation system for the student to provide feedback on their educator teaching quality and skills as well as provide suggestion for improvement from the student perception on the teaching system. The purpose of implementing this evaluation system is to Copyright (C) GLOBAL ACADEMIC EXCELLENCE (M) SDN BHD - All rights reserved 
Volume 3 Issue 6 (March 2021) PP. 61-68

DOI 10.35631/AIJBAF.36006

create continuous improvement or to adopt the culture for better changes in the HEI. On the other hand, this practice will also recommend the revise of course detail to be more quality, timely and flexible.

Transforming the teaching and learning through Kaizen practices in higher education level can benefit the institutional to attain their goals to improvise the education quality that nowadays seems as some significant problems among educator in education institution. Traditionally, the concept of Kaizen first adopted in the industrial sector which was aimed to improve the efficiency or quality improvement in industry. However, in these day and age, some of the education institutions have tried to implement Kaizen in their institution because of the positive feedback and success achieved by many organizations who experienced in practicing Kaizen (Khayum, 2015). Therefore, the objective of this study is to identify the Kaizen practices among accounting students and lecturers in Azman Hashim International Business School.

\section{Literature Review}

Higher education institution comprises of universities or colleges that provide education course beyond the secondary level (Chinta, Kebritchi, \& Ellias, 2016; Sunder, 2016). Currently, higher education institution had no exception in creating ongoing quality improvement on their delivery processes to meet the need and satisfaction of the whole society. Many countries keep on evaluating and creating the best education system for future planning because they admitted that education sector was significant to the country. Lina and Ullah (2019) highlighted that the purpose of implementing suggestion system is to encourage the involvement of all party to think innovatively and creatively in order to generate ideas which will give advantages to the organization. Sunder (2016) explain that Kaizen event as one of the Kaizen practices that focused on targeted continuous improvement area in a certain short period. These Kaizen event implement the lowest-cost for problem solving and decision making to obtain effective end result in a target work area.

Transforming the teaching and learning through Kaizen practices in higher education level can benefit the institutional to attain their goals to improvise the education quality that nowadays seems as some significant problems among educator in education institution. Traditionally, the concept of Kaizen first adopted in the industrial sector which was aim to improve the efficiency or quality improvement in industry. However, in these day and age, some of the education institutions have tried to implement Kaizen in their institution because of the positive feedback and success achieved by many organizations who experienced in practicing Kaizen (Mercado et al., 2016).

Mercado et al. (2016) had demonstrated a study on Kaizen implementation to achieve better quality education system in higher education institution. The researcher had carried out an analysis on the responsibility of students, faculty members and universities towards their assumption and experience due to the continuous improvement decision. They also have to commence their own practices and techniques to distinguish with the Kaizen concept and principle that will set out. The main goals towards this change will promise the worthiness quality of teaching and excellent graduates. Moreover, the changes also allow the lecturer towards better achievement on the course development, create good time among colleagues to perform teamwork and interact to each other, the changes have link with the graduate expectations, as well as encourage the colleague's capabilities to think new ideas for current and future practice.

Copyright $\odot$ GLOBAL ACADEMIC EXCELLENCE (M) SDN BHD - All rights reserved 
Volume 3 Issue 6 (March 2021) PP. 61-68

DOI 10.35631/AIJBAF.36006

Lina and Ullah (2019) had demonstrate a study on Kaizen implementation to achieve better quality education system in higher education institution. The researcher had carried out an analysis on the responsibility of students, faculty members and universities towards their assumption and experience due to the continuous improvement decision. They also have to commence their own practices and techniques to distinguish with the Kaizen concept and principle that will set out. The main goals towards this change will promise the worthiness quality of teaching and excellent graduates.

Thereby, the researcher had obtained an improvement result that have made which they had abolish the unnecessary teaching materials, make an amendment on the learning system format and course objectives, develop more programmes that will sharpen the leadership skills and knowledge among themselves. Moreover, the changes also allow the lecturer towards better achievement on the course development, create good time among colleagues to perform teamwork and interact to each other, the changes have link with the graduate expectations, as well as encourage the colleague's capabilities to think new ideas for current and future practise.

\section{Dimensions of Kaizen}

\section{Training and Awareness}

Training brings up an idea to develop and enhance work performance of employees at any organization. Self-effectiveness and better result of performance can be obtaining throughout the initiatives of training (Elnaga, \& Imran, 2013; Asfaw, 2016). Various method of training can be given to employees such as coaching and mentoring, seminar, orientation and other. Training does not only focus on the potential development, but it also includes to brush up the thinking skills and creativity to generate ideas for the use of decision making.

\section{Quality Management}

According to Kim, Kumar, and Kumar (2012), quality management stimulates the contribution of all functions in the organization towards ongoing improvement and organizational change. It is important to discover and develop good quality management which can help the management to integrate with all cross-functional. Quality management usually focused on any appropriate practices that can allow an organization to enhance their quality performance. As an example, a need to change the learning and teaching environment by utilizing the used of modern technology like smart phone and internet coverage to ease student searching information for study purpose. A well-planned instructions and assessments in the management can facilitate all team functions in the organization to achieve the organization's goals. In order to meet the need and satisfaction for the whole organization, an individual evaluation and suggestion need to be taken for better decision making on quality management improvement.

\section{Continuous Improvement}

Kaizen implementation always focused with the continuing practices in the organization. These practices can make a huge difference on the organization's improvement even with small kind of changes. An ongoing improvement need to be maintained continuously with a proper standard and guidelines (Kregel, 2019). The management are responsible to monitor and control their bottom employees to ensure that they are in line with the standards. Therefore, with this systematic plan of developing continuous improvement, the organization can be achieved to benefit the whole need and satisfaction. 


\section{Motivation and Empowerment}

The opportunity of an organization to become successful is stronger if they have a competitive advantage on motivated employees which these kinds of employees are looking forward the potential on improvement area that they can perform (Manzoor, 2012). Motivation is necessary in assisting employees' behavior for acting towards the organization's objectives and goals. Organizational culture is one of the factors that can influence employee's motivation since they are very expose in various kind of behavior and system. In any organization, it is important to give motivation in order to encourage employees fulfil their job satisfaction. Each employee is desire to be motivated even they have great experience in their work field or they are newly worker. Motivated employees can contribute their effort in accomplishing the improvement in working process.

\section{Methodology}

This research had adopted a quantitative research approached which aims to identify the implementation of Kaizen practices. The questionnaire was distributed to the respondents through an online platform which is online Google Form. The reason of using online Google Form is because of the obstacles to meet face to face with respondents during Movement Control Order (MCO) instructed by the Malaysian government during Covid-19. Therefore, an online Google Form had created for the respondents and the information received from respondent will be kept privately and confidentially for the purpose of this study. The target population of this study is focus on all level of management in the organization including lecturer, staffs and students in Azman Hashim International Business School.

\section{Conceptual Framework}

The proposed research model aims to identify the implementation of Kaizen practices as presented in Figure 1.

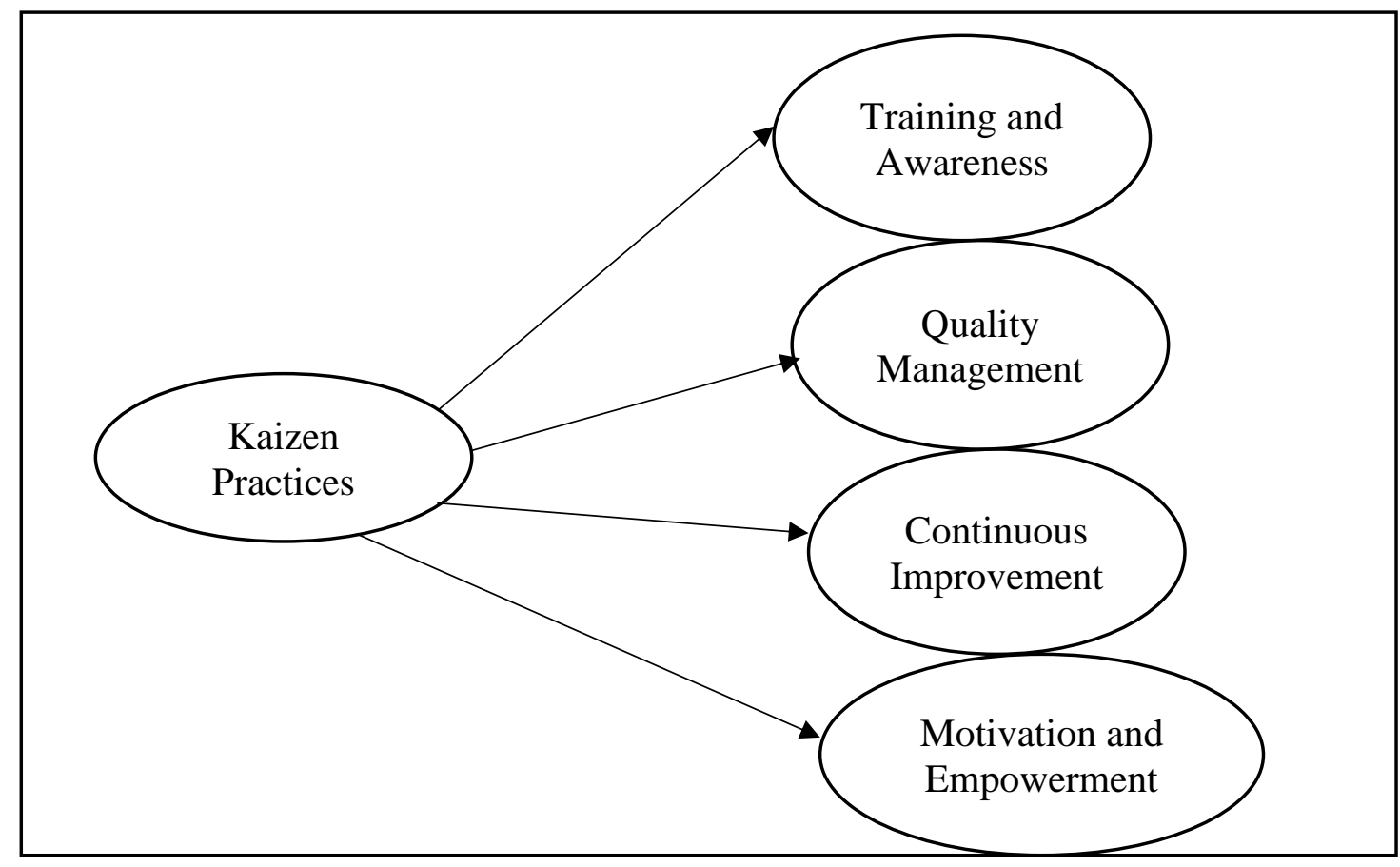

Figure 1: Conceptual Framework 


\section{Hypotheses Development}

\section{Hypothesis 1: Training And Awareness Is Significantly Influence To Organizational Performance}

Training and development refer to programs that provide workers with information, new skills or opportunity for advancement (Elnaga \& Imran, 2013). Training initiatives are the incentive that an individual need to enhance their efficiency and skills as well as increase the productivity in the organization. Successful training is the constructive method designed to achieve the learning required for better performance of the employees.

\section{Hypothesis 2: Continuous Improvement Is Significantly Influence To Organizational Performance}

Mercado et al. (2016) revealed that continuous improvement is a key to obtain an individual satisfaction. This is because, people who obtain satisfaction can motivate them in monitoring their own fate and world. People need to handle a hard effort and work with the determination to attain their goal. Therefore, implementing continuous improvement can influence to enhance the performance in the organization.

\section{Hypothesis 3: Quality Management Is Significantly Influence To Organizational Performance}

It has been proposed that an organization with good leadership capabilities are better in adopting quality management. These organizations often deliver higher quality of product (Laosirihongthong \& Adebanjo, 2013). It is essential if the leaders promote understanding about people need and satisfaction as well as create close relationship with people. This is because, setting up close relationship among people will increasing the individual satisfaction. The leader effort will bring about change in individual attitude as well as leadership guidance and support would allow them for better teamwork.

\section{Hypothesis 4: Motivation And Empowerment Is Significantly Influence To Organizational Performance}

According to Manzoor (2012), individual awareness on their organization's goals, values and management concepts was strongly and greatly linked with the environmental motivation and work satisfaction. Empowerment is one of the key success that can lead to individual's motivation which contribute to constant expansion and organizational growth. Individual engagement and empowerment not only contribute to improve the productivity, efficiency and creativity.

\section{Conclusions}

From the theoretical perspective, this study suggests that the contingency theory can contribute directly to improve Kaizen practices and organizational performance in Azman Hashim International Business School (AHIBS). In particular, the finding of this study is expected to be added to the existing body of knowledge by providing empirical evidence that suggests the relationship between Kaizen practices and organizational performance in Azman Hashim International Business School (AHIBS). Therefore, the research findings would provide new insights for the Kaizen practices in order to improve organizational performance in Azman Hashim International Business School (AHIBS). 
Volume 3 Issue 6 (March 2021) PP. 61-68

DOI 10.35631/AIJBAF.36006

The Kaizen practices will provide a good direction for the management and help them to improve the performance in the organization. However, this study's scope was based on a small sample of organization and the data analyze is limited to the sample that has been chosen. This study has a number of limitations that need to be addressed in future research. Firstly, the population and sample of the survey respondents only target in Azman Hashim International Business School. Secondly, this research only uses the survey technique and based on the quantitative approach. Thus, it is expected that the results of this study will give valuable insights into the implementation of Kaizen practices and in Azman Hashim International Business School. Higher education institutions should grab the opportunity to build close relationship among the colleagues in the organization. Hence, by implementing Kaizen practices is the best strategy and initiatives to change the negative culture within the organizations. Through this way, the education institutions can continue to improve and sustain their effectiveness and efficiency of education system from time to time in the future.

\section{References}

Asaad, M. N. M., Saad, R., \& Yusoff, R. Z. (2015). 5S, Kaizen and organization performance: Examining the relationship and level of implementation using Rasch model in Malaysian automotive company. International Academic Research Journal of Business and Technology, 1(2), 214-226.

Asfaw, B. (2016). Assessment on practices and challenges of Kaizen implementation in selected manufacturing companies of Addis Ababa (Doctoral dissertation). St. Mary's University.

Chen, J. K. (2018). A novel Kaizen technique for service quality: Case study in educational organization. The TQM Journal, 30(4), 269-280.

Chinta, R., Kebritchi, M., \& Ellias, J. (2016). A conceptual framework for evaluating higher education institutions. International Journal of Educational Management, 30(6), 9891002.

Elnaga, A., \& Imran, A. (2013). The effect of training on employee performance. European Journal of Business and Management, 5(4), 137-147.

Kim, D. Y., Kumar, V., \& Kumar, U. (2012). Relationship between quality management practices and innovation. Journal of Operations Management, 30(4), 295-315.

Kregel, I. (2019). Kaizen in university teaching: Continuous course improvement. International Journal of Lean Six Sigma, 10(4), 975-991.

Laosirihongthong, T., Teh, P. L., \& Adebanjo, D. (2013). Revisiting quality management and performance. Industrial Management \& Data Systems, 113(7), 990-1006.

Lina, L. R., \& Ullah, H. (2019). The concept and implementation of Kaizen in an organization. Global Journal of Management and Business Research, 19(1), 9-17.

Mano, Y., Akoten, J., Yoshino, Y., \& Sonobe, T. (2014). Teaching kaizen to small business owners: An experiment in a metalworking cluster in Nairobi. Journal of the Japanese and International Economies, 33, 25-42.

Manzoor, Q. A. (2012). Impact of employee's motivation on organizational effectiveness. Business Management and Strategy, 3(1), 1-12.

Mercado, C. A. I., Bayugo, E. J. S. M., Leynes, Z. L. S., Lontok, C. J. B., Medilla, D. K. M., \& Manongsong, J. L. (2016). Accounting students' learning satisfaction of professional subjects as basis for continuous improvement. Asia Pacific Journal of Education, Arts and Sciences, 3(1), 99-109.

Nazir, S. M. (2013). Kaizen: Imperative characteristic for Indian entrepreneur, an overview. IBMRD's Journal of Management \& Research, 2(1), 381-388.

Copyright $\odot$ GLOBAL ACADEMIC EXCELLENCE (M) SDN BHD - All rights reserved 
Volume 3 Issue 6 (March 2021) PP. 61-68 DOI 10.35631/AIJBAF.36006

Reddy, S. K., \& Karim, S. (2015). Kaizen approach for enhancing quality management practices in HEIs. Establishing, Enhancing and Sustaining Quality Practices in Education, 20(28), 46-55.

Sapungan, R. M., \& Cuarteros, J. B. (2018). Improving teaching and learning through Kaizen and 7th Habit. International Journal Advances in Social Science and Humanities, 4(1), $1-7$.

Sunder M, V. (2016). Constructs of quality in higher education services. International Journal of Productivity and Performance Management, 65(8), 1091-1111. 